\title{
Synaptic Functions of Invertebrate Varicosities: What Molecular Mechanisms Lie Beneath
}

\author{
Carlo Natale Giuseppe Giachello, ${ }^{1}$ Pier Giorgio Montarolo, ${ }^{1,2}$ and Mirella Ghirardi ${ }^{1,2}$ \\ ${ }^{1}$ Department of Neuroscience, University of Torino, Corso Raffaello 30, 10125 Torino, Italy \\ ${ }^{2}$ Istituto Nazionale di Neuroscienze, Corso Raffaello 30, 10125 Torino, Italy
}

Correspondence should be addressed to Carlo Natale Giuseppe Giachello, carlo.giachello@unito.it

Received 30 November 2011; Accepted 27 February 2012

Academic Editor: Volker Korz

Copyright ( 2012 Carlo Natale Giuseppe Giachello et al. This is an open access article distributed under the Creative Commons Attribution License, which permits unrestricted use, distribution, and reproduction in any medium, provided the original work is properly cited.

\begin{abstract}
In mammalian brain, the cellular and molecular events occurring in both synapse formation and plasticity are difficult to study due to the large number of factors involved in these processes and because the contribution of each component is not well defined. Invertebrates, such as Drosophila, Aplysia, Helix, Lymnaea, and Helisoma, have proven to be useful models for studying synaptic assembly and elementary forms of learning. Simple nervous system, cellular accessibility, and genetic simplicity are some examples of the invertebrate advantages that allowed to improve our knowledge about evolutionary neuronal conserved mechanisms. In this paper, we present an overview of progresses that elucidates cellular and molecular mechanisms underlying synaptogenesis and synapse plasticity in invertebrate varicosities and their validation in vertebrates. In particular, the role of invertebrate synapsin in the formation of presynaptic terminals and the cell-to-cell interactions that induce specific structural and functional changes in their respective targets will be analyzed.
\end{abstract}

\section{Introduction}

Interneuronal communication is essential for all nervous system functions. Neurons transmit their signals to one another at specialized structures termed synapses in which a presynaptic and a postsynaptic compartment are both morphologically and functionally distinguished.

Cellular accessibility and the relative simplicity of their nervous system have made invertebrate models, such as Aplysia, Lymnaea, Hirudo, Helix, and Helisoma [1-9], a particularly suitable solution for investigating the formation of synapse and the specificity of neuronal connectivity. A large number of invertebrate neurons can be individually identified and isolated in cell culture, since they share similar size, position, biophysical properties, synaptic connections, and physiological functions among animals of the same species [10]. Therefore, it is even possible to reconstruct in dissociated cell culture synapses between individually identified invertebrate neurons that recapitulate in vitro their in vivo features $[6,7,11-13]$. Culture conditions, specific to each system, promote the regeneration of new neuritic arbors and the establishment of synaptic connections with remarkable accuracy. Thus, cell culture approaches combined with imaging and electrophysiological techniques have allowed neuroscientists to monitor cellular and molecular events underlying neurite outgrowth, synaptogenesis, and synaptic plasticity.

Commonly, vertebrate neurons display a stereotyped polarity in which it is possible to identify well-distinguished areas deputed for receiving and integrating synaptic inputs (dendrites, soma, and proximal axon), for action potential initiation (axon initial segment), and signal propagation (axonal arborization). On the other hand, invertebrate neurons normally lack myelinated axons, and their afferent and efferent processes often branch from the same offshoot of the soma. Although the presence of spine-like processes along dendrites of Drosophila visual interneurons [14] and honeybee calycal interneurons has been observed $[15,16]$, there is no evidence that neurons of other invertebrate models bear dendritic spines with a well-defined morphology as described in vertebrates. Invertebrate synapses are clustered onto varicose-like structures that appear as irregular small 
swellings distributed along neurites. Varicosities have been described in both invertebrate and vertebrate models, such as Helix [7, 17-19], Aplysia [20-24], Lymnaea [25], Helisoma [26], rat cortical neurons [27], pyramidal neurons [28], and hippocampal neurons $[29,30]$.

\section{Initial Steps in the Formation of Varicosities}

Studies in culture have revealed that varicosities can result from the transformation of growth cone into synaptic terminal after the contact of a postsynaptic cell $[31,32]$, as well as along axons even in the absence of a postsynaptic target [27, 29, 33-42] (Figure 1). The formation of functional active zones lacking postsynaptic partners may be attributed to substances used for coating culture surfaces (such as polylysine, polyornithine, and basic growth factor) [37, 43-46], nevertheless this configuration is observed in vivo in many invertebrate [47] and mammalian central nervous system, that is, climbing fibers in cerebellum [48], mossy fibers of the dentate gyrus [49], and primary visual cortex of adult macaque [50].

In this way, the presence of multiple presynaptic regions that are dispersed along the length of the axon allows a single neuron to form en passant synaptic connections with many partners. Thus, we can infer that synapse formation is not a simple result of a physical contact among neurons. Interestingly, it has been demonstrated that Helisoma buccal neuron B5 can form an efficacious chemical synapse with B19 neuron $[13,51]$ within minutes after contact [3]. This mechanism does not imply a target-dependent induction of secretory capabilities. In fact, in neuron B5 the release machinery is assembled through intrinsic developmental mechanisms prior to contact [52]. Moreover, cultured Xenopus spinal neurons, rat hippocampal neurons, and Drosophila neurons show some ability for evoked synaptic vesicle recycling along entire axonal segments, even in the absence of their targets [29, 33, 35-37, 39-41]. Morphological studies performed on Aplysia sensory neurons cultured in contact with postsynaptic neurons as well as in isolated configuration suggest that varicosities are formed either at the tips of advancing growth cones, or along neurites after their advancement, or by splitting of pre-existing varicosities [23, 24, 53, 54].

Actually, the model proposed in the literature [55] includes a series of hierarchical steps that occur through a combination of vesicle trafficking and local recruitment of synaptic proteins. Firstly, a huge accumulation of organelles leads to vesicle cluster formation at the palm of advancing growth cone. During the assembly of presynaptic boutons, clusters of pleiomorphic vesicles have been observed at newly forming synapses [56]. Synaptic vesicle clustering to actin cytoskeleton and the following reorganization in synaptic pools may cause the sequestration of G-actin and other proteins with the consequent slowing of neuritic extension and the swelling of the central area of growth cone. Afterwards, the supply or resources are resumed, and the growth cone may carry on its advance, leaving behind a new varicosity. Finally, the newly formed varicosity is further supplemented with organelles delivered along the axons by anterograde transport. Varicosities host a heterogeneous population of subcellular organelles that include clear and dense core vesicles, mitochondria, and endoplasmic reticulum [54]. Electron microscope studies revealed that the content of varicosities formed by neurons grown in the absence of postsynaptic partners ranges from organelle high-density varicosity to those that are almost free of organelles $[57,58]$.

\section{Molecular Mechanisms at Presynaptic Level: Role of Synapsin}

At presynaptic level, synapsins have a prominent role in regulating the formation and the maturation of new varicosities. Synapsins are a family of synaptic vesicle-associated phosphoproteins identified in a wide range of vertebrate and invertebrate organisms [59-63]. These proteins are predominantly localized at the surface of synaptic vesicles [64-66] and maintain vesicle pool organization tethering synaptic vesicles to actin cytoskeleton. Thus, vesicle mobilization may be regulated by synapsins in a phosphorylation-dependent manner. Real-time imaging in hippocampal cultures has demonstrated that phosphorylated synapsin dissociates from vesicle clusters during tetanic stimulation [67], delivering vesicles from reserve pool to replenish the readily releasable pool, which has been depleted upon activity [68]. Synapsins are multidomain proteins sharing a common $\mathrm{N}$-terminal region composed of three domains (domains $\mathrm{A}, \mathrm{B}$, and $\mathrm{C}$ ) that are highly conserved across isoforms and species with the exception of domain $\mathrm{B}$. The C-terminal domain composition (D-I) is more variable and derives from alternative splicing events $[61,69]$.

While in mammals the different isoforms of synapsin proteins are coded by three distinct genes, invertebrates and lower vertebrates contain only one single gene. It may be plausible that synapsin family originates from one ancestral precursor, which was subjected to duplication events when vertebrates diverged from invertebrates [61]. The hypothesis of an ancestral single synapsin gene has been validated after cloning and sequencing of synapsin in some invertebrate species such as two ecdysozoans, the fly Drosophila melanogaster [70] and the nematode Caenorhabditis elegans [61], and three lophotrochozoans, the mollusks Loligo pealei [71], Aplysia californica [72], and Helix pomatia [73]. Therefore, the evolution of these proteins in the different phyla correlates with the development of a progressively more complex nervous system.

There are many pieces of evidence that synapsins play a role in axon elongation and synapse formation. It has been demonstrated that synapsin I and II regulate synaptic functions following the early neurogenesis in mouse brain [74]. Synapsin III is expressed mainly in early phases of neuronal development and is highly concentrated in growth cones [75]. Moreover, the onset of presynaptic maturation at Xenopus neuromuscular junctions is causally related to the onset of synapsin expression [76], indeed experimentally elevated levels of synapsin I [77] or synapsin IIa [78] accelerate presynaptic maturation characterized by a precocious assembly of active zone structures, organization of synaptic 


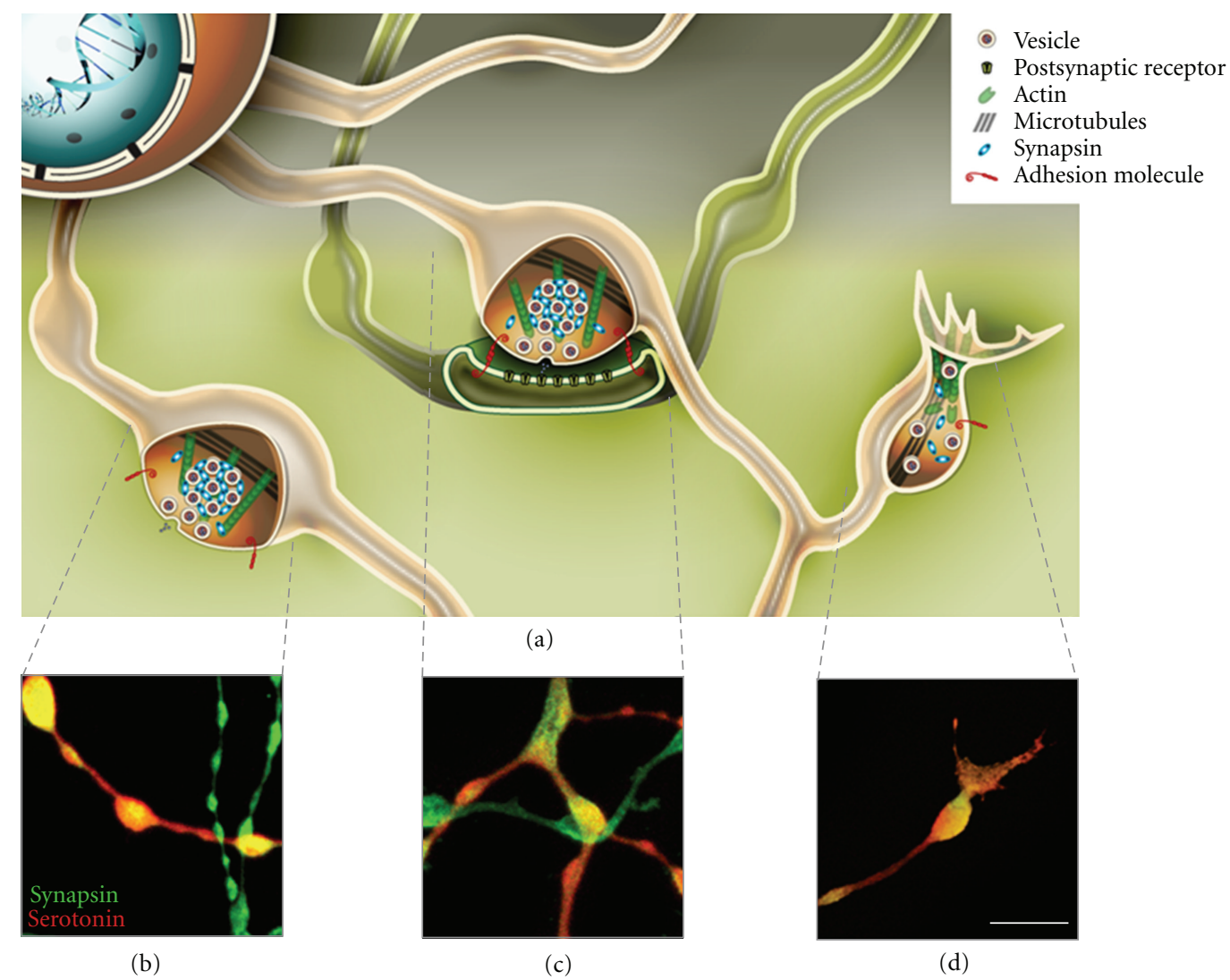

Figure 1: Schematic representation of the three most common types of varicosities observed in invertebrate neuronal cultures (a). The bottom panels show confocal acquisitions of neurites belonging to the serotonergic Helix neuron $\mathrm{C} 1$ cocultured with its physiological target B2 and immunostained with anti-serotonin (red) and anti-synapsin (green) antibodies. In these sample images it is possible to identify a varicosity without a postsynaptic target in which neurotransmitter release can be detected using functional dyes or electrophysiological techniques (b); a presynaptic varicosity interconnected with its postsynaptic counterpart (c); a newly formed varicosity derived from an advancing growth cone in which well-defined synaptic vesicle pools have not yet organized (d). Scale bar: $10 \mu \mathrm{m}$.

vesicle pools, and also a rapid formation of thickenings of postsynaptic muscle cell membrane [79]. Interestingly, even the overexpression of synapsin in non-neuronal cells results in the formation of neurite- and synaptic-like structures similar to varicosities [80].

As in vertebrates, synapsin expression correlates well with the time course of presynaptic terminal maturation and synaptogenesis in mollusks, such as Helix and Aplysia. In isolated Helix neurons, immunostaining for mammalian synapsin I appears uniformly distributed in the cell body, the distal axonal segments and the growth cones. The contact and the formation of a chemical connection with an appropriate juxtaposed target induce a redistribution of the synapsin mainly in varicosity-like structures immunoreactive for the neurotransmitter serotonin along neurites close to the target neuron [19], similar to the changes in synapsin I distribution following synaptic contacts in hippocampal neurons developing in culture [81]. Interestingly, the number of synapsin-positive varicosity-like structures increases progressively parallel to the enhancement in the mean amplitude of the postsynaptic potentials recorded at the same times in Helix cocultures.

A distribution of synapsin in distinct puncta along neurites has also been shown in neurons of Aplysia punctata
[19] and of Aplysia californica [72] where synapsin undergoes dispersion following serotonin and TGF $\beta 1$ treatments that induce its phosphorylation mediated by PKA [72] and MAPK kinases [82], respectively. Therefore, the phosphorylation of Aplysia synapsin may result in its dissociation from synaptic vesicles in processes activated by neuromodulators and growth factors involved both in modulation of neurotransmitter release and in remodelling of growing neurons during development.

To study the synaptic fidelity of neuronal regenerating connections in culture, a multitude of experiments about target recognition during synaptogenesis has been performed in invertebrate neurons [4, 83-87]. Identified motoneurons, isolated from the buccal ganglia of Helisoma trivolvis, display selective synapse formation in culture $[3,51]$. In particular, the identified B19 neuron forms appropriate cholinergic connections with buccal muscle fibers, but not with other buccal neurons [88].

In Helix nervous system the giant metacerebral neuron C1, homologous of the Aplysia MGC [89], physiologically forms a serotonergic monosynaptic connection with the giant neuron B2 in the buccal ganglia [90]. In vitro studies demonstrated that the presence of a non-physiological target neuron C3 results in a general inhibitory effect on the 
maturation of the presynaptic terminals of neuron C1, reducing both the number of presynaptic varicosities and their ability to release neurotransmitter in the presynaptic neuron [91], through mechanisms that involve the downregulation of both MAPK/Erk and PKA pathways [92]. These pathways are rapidly activated by the contact with the physiological target neuron B2 that can quickly reverse the wrong target-induced inhibition.

In Helix $\mathrm{C} 1$ neurons cultured in contact with a wrong target C3, injection of bovine synapsin I has been shown to exert an enhancing effect on the efficiency of the neurotransmitter release machinery [93]. Interestingly, the injected synapsin was able to rescue neurotransmitter release strongly depressed by the presence of the non-physiological target bringing it to levels comparable to those observed when the C1 neuron is cocultured with its physiological target B2 [91]. This suggests that exogenous synapsin I may accelerate the maturation or simply disinhibit the quantal release mechanisms by affecting cytoskeleton assembly and/or synaptic vesicle clustering in Helix presynaptic terminals, in agreement with the results obtained by injection of synapsin I or II into embryonic Xenopus neurons that accelerates both the morphological and functional development of synapses [7779].

\section{Synapsin Phosphorylation and Synapse Formation}

Further experiments in Helix neurons in culture have analyzed the role of specific domains of synapsin in regulating structure and activity of synapses [73, 94, 95]. A multiple alignment of the primary structure of Helix synapsin [73] with Aplysia synapsin [72] and other mammalian orthologs reveals the high phylogenetic conservation of the PKA/CaMKI/IV phosphorylation site located in the $\mathrm{N}$ terminal domain A (Ser-9). The phosphorylation of this site by either PKA or CaMKI/IV is necessary for the enhancement of neurotransmitter release from neuron $\mathrm{C} 1$ to overcome the inhibitory effect of the wrong target in C1-C3 soma-soma coculture, since the facilitating effect due to the injection of exogenous wild-type synapsin is maintained in the presence of the pseudo-phosphorylated form and virtually lost after the injection of the non-phosphorylatable mutant. Moreover, the functional effects of gastropod synapsin are associated with a phosphorylation-dependent ultrastructural rearrangement of neurons $\mathrm{C} 1$. In fact, electron microscopy analysis showed that in the region of contact between $\mathrm{C} 1$, overexpressing wild-type synapsin, and neuron C3 there were dense interdigitations of microtubule-packed neuritelike processes with the appearance of dense core synaptic vesicle clusters typical of $\mathrm{C} 1$, that were virtually absent in uninjected C1-C3 pairs or after injection of the nonphosphorylatable domain A mutant [94].

Studies on vesicle dynamics in growth cones [96] show a critical role of the PKA phosphorylation site in synapsin I, suggesting that the same molecular mechanisms involved in modulating neurotransmitter release from mature nerve terminals may also underlie the activity of the protein in developing terminals. The increase in cAMP in the presynaptic terminal following the contact with the postsynaptic target [97] may regulate synapsins activity in the control of synaptic vesicle distribution and recycling leading to the transformation of the growth cone into a mature presynaptic bouton. Recently, the overexpression of synapsin domain A phosphomutants in mice lacking endogenous synapsins has restated that this phosphorylation site plays an important role in controlling synapses formation. While the presence of the pseudo-phosphorylated form can accelerate synapse formation, the overexpression of the non-phosphorylatable mutant may cause a significant decrease in the total amount of both glutamatergic and GABAergic synapses during development [98].

In addition to PKA pathway, the phosphorylation of synapsin by MAPK/Erk kinase has also a critical role in the formation of synapses between Helix neurons in culture [95], consistent with a lot of evidence supporting the role of MAPK/Erk kinase in neurotrophic regulation of synapse formation and plasticity in vertebrate and invertebrate models [99-104]. Helix synapsin bears two putative MAPK/Erk consensus sites in domain B, Ser36 and Ser42, that are highly conserved among the known invertebrate synapsin proteins and might represent homologous MAPK/Erk phosphorylation sites to sites 4 and 5 of mammalian synapsin [105].

Overexpression of both MAPK/Erk phosphomutants induce a significant reduction of the presynaptic differentiation of the injected neuron and of the number of synaptic connections between the paired cells. In addition, the basal amplitude of the postsynaptic potentials recorded in Helix B2-B2 neurons is markedly reduced following injection of the non-phosphorylatable MAPK/Erk mutant while it is slightly decreased by the injection of the pseudo-phosphorylated MAPK/Erk mutant. Both mutants have no effect on the rising time of the postsynaptic potentials and do not induce any changes in the neurite outgrowth, suggesting that the reduction in synaptic strength occurs in the absence of changes in neurotransmitter release kinetics and ruling out the possibility that the altered connectivity depends on impairment in neurite growth. These observations suggest that MAPK-dependent synapsin phosphorylation regulates the occurrence of chemical synapses through a growth-independent mechanism [95]. The similar negative effect of both non-phosphorylatable and pseudo-phosphorylated synapsin mutants on synaptic formation suggests that cycles of MAPK/Erk phosphorylation may play a fundamental role in regulating synapsin activity during synaptogenesis, perhaps acting on cytoskeletal assembly and vesicle clustering at synaptic terminals, as suggested by the role of MAPK/Erk phosphorylation in modulating synapsin affinity for actin [105].

All the effects observed with mutagenesis experiments described so far cannot be ascribed to mistargeting of synapsin localization. Confocal acquisitions of soma-soma Helix neurons cocultures overexpressing GFP-conjugated synapsin phosphomutants for either PKA/CaMKI/IV or MAPK/Erk in the presynaptic compartment display a deeper clusterization pattern but the same localization observed for the wild-type form. In particular, ectopic synapsins are 
present in presynaptic neurons with a preferential localization in the contact area with the postsynaptic target and along presynaptic neurites projecting onto the postsynaptic cell, in the areas of the soma-soma pairs containing the majority of the synaptic vesicle clusters and synaptic structures. Therefore, the phosphorylation of the synapsin Nterminus seems not to be implicated in the correct targeting of Helix synapsin, consistent with the observation in cultured hippocampal neurons where the deletion of synapsin domain A does not significantly impair the synaptic targeting of mammalian synapsins [106]. The higher degrees of clustering of overexpressed GFP-tagged synapsin mutants compared with the wild-type protein are possibly due to a stronger association of synapsin mutants with synaptic vesicles and/or to a lower rate of its dispersion and reclustering cycles $[67,107]$. Conversely, the pseudo-phosphorylated mutants show a very low degree of clustering and appear uniformly diffuse along neurites. These observations are consistent with previous morphological studies showing that serotonininduced dispersion of synapsin clusters in Aplysia neurons depends on both PKA and MAPK/Erk activity [72], and that PKA and MAPK/Erk phosphorylation regulates the mobility of synapsin as well as the trafficking of synaptic vesicles in nerve terminals upon stimulation [108].

\section{Synapsin Phosphorylation and Plasticity}

For many years the studies of synapsin functions have been focalized on synaptic plasticity rather than synaptogenesis. Synapsin proteins are implicated in maintenance of presynaptic vesicular pools and in the regulation of vesicle mobility among them during short-term plasticity [109111]. In particular, synapsins appear to have a fundamental role in the expression of post-tetanic potentiation (PTP) since both genetically altered mice and Aplysia synapses exhibit a marked impairment of PTP after genetic deletion or neutralization of synapsin I and/or synapsin II [109, 112]. Interestingly, synaptic vesicle mobilization from the reserve pool during PTP in Drosophila is strongly dependent on PKA activation $[113,114]$. Phosphorylation of synapsin domain A might also modulate PTP by altering the presynaptic release probability as shown in PTP at the calyx of Held synapse [115] that may be mediated by the activation of CaMKs [116]. However, microinjection of domain A peptide into the squid giant synapse had no effect on vesicle pool size, synaptic depression, or transmitter release kinetics, indicating that this domain may be predominantly involved in regulating synaptic vesicle trafficking at pre-docking stages [117]. Presynaptic overexpression of the Helix synapsin non-phosphorylatable mutant in domain A specifically impairs PTP, while the overexpression of the wild-type form has no effect on peak amplitude or time course of PTP [73]. Similarly, these results have been confirmed at Aplysia synapses [118]. In addition, PTP expression in Helix neurons critically depends on MAPK/Erk activation [95], which might occur upon intracellular calcium buildup during the tetanus $[119,120]$ or via crosstalk with other calcium-dependent pathways [121-124]. Although
MAPK/Erk activity does not appear to be required for shortterm heterosynaptic facilitation induced by serotonin at Aplysia sensory-motor synapses $[8,125,126]$, other studies in invertebrates show that modulation of short- and longterm synaptic plasticity paradigms is mediated by MAPK/Erk [82, 127-129]. An involvement of MAPK/Erk in short-term plasticity is also supported by studies in transgenic mice that express a constitutively active form of $\mathrm{H}$-Ras, which exhibit an enhancement of paired-pulse facilitation and long-term potentiation that is dependent on MAPK/Erk activation [130].

As demonstrated by the studies described above, the same molecular pathways and effectors that regulate the formation of functional synaptic contacts are also involved in synaptic transmission and plasticity. Even if these mechanisms acting at presynaptic level seem to be intrinsically regulated, the presence of a target cell during synaptogenesis has a prominent role in triggering the formation and maturation of specialized structures in both pre- and postsynaptic neurons.

\section{Synapse Formation: Crosstalk between Pre- and Postsynaptic Sites}

At postsynaptic level, synapse formation requires a coordinated assembly of synaptic structures conferring the competence to translate the presynaptic signal into a postsynaptic response. In vertebrate neurons, two important steps are the formation of a protrusion that differentiates into a dendritic spine and the formation of a postsynaptic density facing the active zone. These events require the involvement of a multitude of different proteins, which have been partially identified and characterized. Actually, several models have been proposed in spinogenesis: spines may derive either from the stabilization of an initial filopodium after the contact with the axon [131-133], or from filopodium-independent sprouting [134, 135], or, alternatively, they might initially grow without synaptic contact [136-142].

Considering the requirement of a synaptic contact, several protein families have been proposed to trigger spinogenesis mediating cell-to-cell communication, such as cadherins, neuroligin- $\beta$-neurexin cell adhesion complexes, and ephrins/Eph receptors [143-145]. Although these molecules have been shown to play a role in the various aspects of synaptogenesis, matching pre- and postsynaptic components, no single protein factor has been found to be essential for all these processes, from initial synapse specification to the formation of functional connections.

Cadherins are a large family of $\mathrm{Ca}^{2+}$-dependent, homophilic, cell-surface adhesion molecules [146-152]. Both Ecadherins and $\mathrm{N}$-cadherins are present in synapses, and they are symmetrically localized in the adhesive junctions that surround the active zone in the presynaptic terminal and the postsynaptic density [146]. In cultured hippocampal neurons, $\mathrm{N}$-cadherin is ubiquitary expressed in all synapses only at early stages of development, then becomes restricted to a subpopulation of excitatory synapses during maturation [153]. Recent studies have linked these proteins to dendritic 
spine morphogenesis. A delay in spine formation has been observed in cultured hippocampal neurons overexpressing a dominant-negative form of $\mathrm{N}$-cadherin, lacking part of the extracellular domain. Although the loss of $\mathrm{N}$-cadherin activity promotes the appearance of immature filopodia with irregular shapes, synaptic contacts are retained. Moreover, the presence of dominant-negative $\mathrm{N}$-cadherin impairs the localization of both presynaptic and postsynaptic protein markers, that is, synapsin and PSD-95, respectively [154]. This effect seems to be more pronounced at early stages of synaptogenesis, suggesting that cadherins may be more involved in synapse formation rather than stabilization and maturation.

Nevertheless the role of classical cadherins in triggering synapse formation is still debated. Indeed genetic studies in Drosophila has greatly contributed to determining the function of $\mathrm{N}$-cadherins in vivo. Loss of $\mathrm{N}$-cadherin in Drosophila embryos affects the trajectories of longitudinal CNS axons and the guidance of growth cones [155]. It has been demonstrated that $\mathrm{N}$-cadherin is important for coordinating the targeting of multiple neuronal types, such as R7 photoreceptor axons and L1-L5 lamina neurons, to the right target layer in the medulla neuropil of the visual system [156-159]. Drosophila contains 12 isoforms of Ncadherin, but the expression of a single isoform is sufficient to rescue null mutations, suggesting functional redundancy [159]. Thus, these observations indicate that cadherins may be involved in target recognition and perhaps stabilization of early synaptic contact sites but not in the induction of synapse formation.

Another protein, neuronal-cell adhesion molecule $(\mathrm{N}$ CAM), belonging to the $\mathrm{Ca}^{2+}$-independent cell adhesion molecules of the immunoglobulin superfamily, is also present in synapses [160-164]. This protein bears fibronectin type III repeats in the extracellular domain and a short cytoplasmic domain, anchored to the cytoskeleton, which interact with intracellular signaling pathways $[165,166]$. In vitro studies showed that several identified CAM members regulate the number of synaptic contacts, their morphology and functions; however a strong evidence that any of these molecules is necessary for synapse formation in vivo is lacking, probably suggesting a redundancy in their functions. In cell cultures, N-CAMs accumulate quickly at sites of contact formation during the initial assembly of synaptic components [167]. Through interaction with spectrin-coated trans-Golgi-derived organelles, N-CAM may promote the accumulation of those postsynaptic proteins that are necessary to form the synaptic contact [168]. In fact, a reduction in size of postsynaptic densities and an impaired recruitment of spectrin, NMDA receptors, and CaMKIIa to the synapse is observable in neurons lacking N-CAM [169]. Furthermore, studies on mixed cultures of hippocampal neurons from N-CAM knockout and wild-type mice have revealed that postsynaptic N-CAM promotes the formation and increases the strength of excitatory synapses in concert with NMDA receptor activity [170].

In literature a large amount of evidence that suggest the involvement of N-CAM not only in neuronal development, but also in synapse plasticity, results from invertebrate models [171-179]. In Drosophila, the concentration of fasciclin II, homologue of vertebrate N-CAM, regulates sprouting and the capability of neurons to form new synaptic contacts $[177,178]$. In nerve-muscle cocultures from Xenopus embryos, the percentage of functional neuromuscular contacts is decreased by means of antibody against N-CAM [180].

In Aplysia, apCAM is predominantly expressed at synaptic contacts $[172,181]$ and modulates synapse formation and long-term plasticity at sensory-motor synapses [172, $179,182-186]$. The ability of sensory neuron to form in vitro chemical connections with motoneuron L7, detected as number of branches and varicosities, correlates with the expression level of apCAM on different regions of the postsynaptic cell L7 [184]. Moreover, a reduction in fasciculation of growth cones has been observed with the preincubation of isolated sensory or motoneurons with a monoclonal antibody against apCAM [172, 181, 187]. While the addition of the antibody on preformed sensory-motor cocultures results in a failure of serotonin-induced long-term changes in synaptic efficacy and the concomitant morphological changes of sensory neuron, such as formation of new varicosities, without altering the transmission of pre-existing synapses and their short-term modulation [185]. Interestingly, the same anti-apCAM antibody recognizes apCAM-like proteins of the Helix nervous system. The neurotransmitter releasing ability of Helix neuron $\mathrm{C} 1$ is detectable when it is cultured alone or in presence of its physiological target B2, whereas it is inhibited by the presence of the wrong target C3 $[19,91]$. In C1-C3 cocultures, the buildup of neurotransmitter release triggered by the appropriate target B2 is prevented by preincubation of this neuron with anti-apCAM antibody [188], confirming that N-CAM orthologs may play an important role during the contact of two synaptic partners in modulate the efficiency of excitation-secretion coupling.

One potential signaling cascade implicated in this phenomenon is PKC $[189,190]$, since the presence of apCAM on membrane of motoneuron L7 and the activation of Aplysia PKC isoforms PKC Apl II are both necessary events for the initial synapse formation and the increase of sensorin expression by sensory neurons [191]. Therefore, apCAM exposed on L7 membrane surface may activate signaling cascades not only in the motor neuron itself, but also in the coupled sensory neuron via the heterophilic receptor to regulate both pre- and postsynaptically the expression of effectors necessary for the assembly of functional synapses [169, 192-197].

Based on invertebrate Drosophila Fasciclin II and Aplysia apCAM sequences, a database-search analysis resulted in an identification of a similar protein in vertebrates, called SynCAM [198]. SynCAM is a transmembrane member of the Ig superfamily that mediates $\mathrm{Ca}^{2+}$-independent homophilic interactions and displays a structure similar to the nectins [199]: 3 Ig-domains followed by an intercellular C-terminal PDZ-binding motif able to bind the synaptic scaffolding proteins CASK and syntenin. High level of SynCAM expression has been detected in young rat brain in the first few weeks after birth, corresponding with the main period of synaptogenesis. Overexpression studies in cultured hippocampal neurons confirmed that SynCAM promotes 
synapse formation and increases spontaneous synaptic activity while its isolated cytoplasmic tail inhibits synaptic function, perhaps by acting as a dominant negative [198]. Remarkably, this protein has the ability to promote the formation of active presynaptic terminals in non-neuronal cells, when cocultured with hippocampal neurons [198]. Hence, SynCAM may act at multiple stages of synaptogenesis from the initial synaptic contact to the modulation of neurotransmitter release. However, its effects on dendritic spine morphology remain to be determined.

\section{Synapse Modulation and Plasticity: Role of Adhesion Molecules}

Once a functional contact is established, the new synapse goes through a series of maturation processes that is likely to be regulated by neural activity. For example, hippocampal synapses undergo structural changes after long-term potentiation (LTP) in vitro and experience in vivo [200, 201]. Generally, at postsynaptic level, newly formed spines acquire a postsynaptic density and increase their volume which closely correlates with the exposure in membrane of additional AMPA receptors [202] and the reorganization of the actin cytoskeleton [203]. These processes are strictly associated with the induction of LTP [139, 200, 204-206].

Before the large number of data collected from hippocampal neurons about the involvement of adhesion molecules, such as N-CAM, in long-term potentiation [160, 161, $166,176,207-211]$, early studies about long-term modifications were performed on invertebrate models. In particular, an important step in our understanding of N-CAM functions comes from studies on long-term functional and structural plasticity of the Aplysia sensory-motor synapse. ApCAM is expressed at the highest levels at sites of synaptic contact between sensory and motor neurons in culture, consistent with its in vivo distribution [181]. Long-term facilitation induced by serotonin application is accompanied by the formation of new branches and varicosities in sensory neuron $[21,212]$. On the other hand, long-term depression of the same synapse by the neuropeptide Phe-Met-Arg-Pheamide (FMRFamide) is correlated with the loss of presynaptic sensory neurites and varicosities $[213,214]$. Both modifications of synaptic efficiency involve a rapid and cellspecific change in the distribution of apCAM. The treatment with 5-HT causes a downregulation of apCAM from the surface of the sensory neuron via a cAMP-dependent increase in endocytosis of clathrin-coated vesicles [172, 182, 215], while application of FMRFamide induces a downregulation of apCAM from the surface of the target motor neuron by a similar cAMP-dependent mechanism [183, 187]. Consistent with these observations, transgenic mice in which N-CAM has been depleted showed deficits in learning and memory [216]. Furthermore, the interference with N-CAM levels through specific antibodies or suppression of NCAM results in a reduced or even abolished LTP in the CA1 region of the hippocampus [161, 176, 217].

\section{Concluding Remarks}

Synaptogenesis is a complex process that results in the assembly of a functional release machinery in the presynaptic terminals and the formation of specialized structures at the corresponding postsynaptic level. In recent years, considerable progress has been reached in understanding the cellular and molecular mechanisms of vertebrate synaptogenesis. New techniques and approaches have allowed scientists to characterize several molecules that regulate not only when and where synapses are formed but also their continuous plastic modifications. Beside this, it is important to mention the contribution of pioneering experimental studies performed on invertebrate models that permitted the identification of the basic mechanisms of neuronal functions implicated in behavioral responses that are phylogenetically conserved in vertebrate animals.

\section{Acknowledgments}

The authors would like to thank Dr. Ferdinando Fiumara for his comments and support. This work was supported by Grants from Italian Ministry of the University and Research Grant (PRIN 2006 and 2009 grants to P. G. Montarolo) and Compagnia di San Paolo (to P. G. Montarolo and M. Ghirardi).

\section{References}

[1] P. G. Haydon, "The formation of chemical synapses between cell-cultured neuronal somata," Journal of Neuroscience, vol. 8, no. 3, pp. 1032-1038, 1988.

[2] D. L. Glanzman, E. R. Kandel, and S. Schacher, "Identified target motor neuron regulates neurite outgrowth and synapse formation of Aplysia sensory neurons in vitro," Neuron, vol. 3, no. 4, pp. 441-450, 1989.

[3] P. G. Haydon and M. J. Zoran, "Formation and modulation of chemical connections: evoked acetylcholine release from growth cones and neurites of specific identified neurons," Neuron, vol. 2, no. 5, pp. 1483-1490, 1989.

[4] N. I. Syed, A. G. M. Bulloch, and K. Lukowiak, "In vitro reconstruction of the respiratory central pattern generator of the mollusk Lymnaea," Science, vol. 250, no. 4978, pp. 282285, 1990.

[5] M. Klein, "Synaptic augmentation by 5-HT at rested Aplysia sensorimotor synapses: independence of action potential prolongation,” Neuron, vol. 13, no. 1, pp. 159-166, 1994.

[6] F. Fernandez-de-Miguel and P. Drapeau, "Synapse formation and function: insights from identified leech neurons in culture," Journal of Neurobiology, vol. 27, no. 3, pp. 367-379, 1995.

[7] M. Ghirardi, A. Casadio, L. Santarelli, and P. G. Montarolo, "Aplysia hemolymph promotes neurite outgrowth and synaptogenesis of identified Helix neurons in cell culture," Invertebrate Neuroscience, vol. 2, no. 1, pp. 41-49, 1996.

[8] K. C. Martin, D. Michael, J. C. Rose et al., "MAP kinase translocates into the nucleus of the presynaptic cell and is required for long-term facilitation in Aplysia," Neuron, vol. 18, no. 6, pp. 899-912, 1997.

[9] S. Schacher and F. Wu, "Synapse formation in the absence of cell bodies requires protein synthesis," Journal of Neuroscience, vol. 22, no. 5, pp. 1831-1839, 2002. 
[10] E. R. Kandel, Cellular Basis of Behavior: an Introduction to Behavioral Neurobiology, W. H. Freeman and Company, 1976.

[11] S. Schacher, S. G. Rayport, and R. T. Ambron, "Giant Aplysia neuron R2 reliably forms strong chemical connections in vitro," Journal of Neuroscience, vol. 5, no. 11, pp. 2851-2856, 1985.

[12] D. L. Glanzman, "Postsynaptic regulation of the development and long-term plasticity of Aplysia sensorimotor synapses in cell culture," Journal of Neurobiology, vol. 25, no. 6, pp. 666693, 1994.

[13] P. G. Haydon and M. J. Zoran, "Retrograde regulation of presynaptic development during synaptogenesis," Journal of Neurobiology, vol. 25, no. 6, pp. 694-706, 1994.

[14] F. Leiss, E. Koper, I. Hein et al., "Characterization of dendritic spines in the Drosophila central nervous system," Developmental Neurobiology, vol. 69, no. 4, pp. 221-234, 2009.

[15] R. G. Coss, J. G. Brandon, and A. Globus, "Changes in morphology of dendritic spines on honeybee calycal interneurons associated with cumulative nursing and foraging experiences," Brain Research, vol. 192, no. 1, pp. 49-59, 1980.

[16] J. G. Brandon and R. G. Coss, "Rapid dendritic spine stem shortening during one-trial learning: the Honeybee's first orientation flight," Brain Research, vol. 252, no. 1, pp. 51-61, 1982.

[17] K. Elekes and J. Ude, "An immunogold electron microscopic analysis of FMRFamide-like immunoreactive neurons in the CNS of Helix pomatia: ultrastructure and synaptic connections," Journal of Neurocytology, vol. 22, no. 1, pp. 1-13, 1993.

[18] S. Ratte and R. Chase, "Synapse distribution of olfactory interneurons in the procerebrum of the snail Helix aspersa," The Journal of Comparative Neurology, vol. 417, pp. 366-384, 2000.

[19] G. Cibelli, M. Ghirardi, F. Onofri et al., "Synapsin-like molecules in Aplysia punctata and Helix pomatia: identification and distribution in the nervous system and during the formation of synaptic contacts in vitro," European Journal of Neuroscience, vol. 8, no. 12, pp. 2530-2543, 1996.

[20] C. H. Bailey and M. Chen, "Morphological basis of long-term habituation and sensitization in Aplysia," Science, vol. 220, no. 4592, pp. 91-93, 1983.

[21] P. G. Montarolo, P. Goelet, V. F. Castellucci, J. Morgan, E. R. Kandel, and S. Schacher, "A critical period for macromolecular synthesis in long-term heterosynaptic facilitation in Aplysia," Science, vol. 234, pp. 1249-1254, 1986.

[22] C. H. Bailey and M. Chen, "Long-term memory in Aplysia modulates the total number of varicosities of single identified sensory neurons," Proceedings of the National Academy of Sciences of the United States of America, vol. 85, no. 7, pp. 23732377, 1988.

[23] Y. Hatada, F. Wu, Z. Y. Sun, S. Schacher, and D. J. Goldberg, "Presynaptic morphological changes associated with longterm synaptic facilitation are triggered by actin polymerization at preexisting varicositis," Journal of Neuroscience, vol. 20, no. 13, Article ID RC82, 2000.

[24] P. W. Grabham, F. Wu, S. Schacher, and D. J. Goldberg, "Initiating morphological changes associated with long-term facilitation in Aplysia is independent of transcription or translation in the cell body," Journal of Neurobiology, vol. 64, no. 2, pp. 202-212, 2005.

[25] P. Buma, "Synaptic and nonsynaptic release of neuromediators in the central nervous system," Acta Morphologica Neerlando-Scandinavica, vol. 26, no. 2-3, pp. 81-113, 1988.
[26] H. R. Khan, D. A. Price, K. E. Doble, M. J. Greenberg, and A. S. M. Saleuddin, "FMRFamide-related peptides, partial serotonin depletion, and osmoregulation in Helisoma duryi (Mollusca: Pulmonata)," The Journal of Comparative Neurology, vol. 393, pp. 25-33, 1998.

[27] F. D. Morgenthaler, G. W. Knott, J. C. F. Sarria et al., "Morphological and molecular heterogeneity in release sites of single neurons," European Journal of Neuroscience, vol. 17, no. 7, pp. 1365-1374, 2003.

[28] T. Umeda, T. Ebihara, and S. Okabe, "Simultaneous observation of stably associated presynaptic varicosities and postsynaptic spines: morphological alterations of CA3-CA1 synapses in hippocampal slice cultures," Molecular and Cellular Neuroscience, vol. 28, no. 2, pp. 264-274, 2005.

[29] S. R. Krueger, A. Kolar, and R. M. Fitzsimonds, "The presynaptic release apparatus is functional in the absence of dendritic contact and highly mobile within isolated axons," Neuron, vol. 40, no. 5, pp. 945-957, 2003.

[30] S. Sankaranarayanan, P. P. Atluri, and T. A. Ryan, "Actin has a molecular scaffolding, not propulsive, role in presynaptic function," Nature Neuroscience, vol. 6, no. 2, pp. 127-135, 2003.

[31] R. P. Rees, M. B. Bunge, and R. P. Bunge, "Morphological changes in the neuritic growth cone and target neuron during synaptic junction development in culture," The Journal of Cell Biology, vol. 68, no. 2, pp. 240-263, 1976.

[32] J. Buchanan, Y. A. Sun, and M. M. Poo, "Studies of nervemuscle interactions in Xenopus cell culture: fine structure of early functional contacts," Journal of Neuroscience, vol. 9, no. 5, pp. 1540-1554, 1989.

[33] Y. A. Sun and M. M. Poo, "Evoked release of acetylcholine from the growing embryonic neuron," Proceedings of the $\mathrm{Na}$ tional Academy of Sciences of the United States of America, vol. 84, no. 8, pp. 2540-2544, 1987.

[34] J. Christenson, S. Cullheim, S. Grillner, and T. Hokfelt, "5-Hydroxytryptamine immunoreactive varicosities in the lamprey spinal cord have no synaptic specializations-an ultrastructural study," Brain Research, vol. 512, no. 2, pp. 201209, 1990.

[35] M. Matteoli, K. Takei, M. S. Perin, T. C. Sudhof, and P. De Camilli, "Exo-endocytotic recycling of synaptic vesicles in developing processes of cultured hippocampal neurons," The Journal of Cell Biology, vol. 117, no. 4, pp. 849-861, 1992.

[36] K. Kraszewski, O. Mundigl, L. Daniell, C. Verderio, M. Matteolli, and P. De Camilli, "Synaptic vesicle dynamics in living cultured hippocampal neurons visualized with CY3conjugated antibodies directed against the lumenal domain of synaptotagmin," Journal of Neuroscience, vol. 15, no. 6, pp. 4328-4342, 1995.

[37] Z. S. Dai and H. B. Peng, "Dynamics of synaptic vesicles in cultured spinal cord neurons in relationship to synaptogenesis," Molecular and Cellular Neurosciences, vol. 7, no. 6, pp. 443-452, 1996.

[38] A. Prokop, M. Landgraf, E. Rushton, K. Broadie, and M. Bate, "Presynaptic development at the Drosophila neuromuscular junction: assembly and localization of presynaptic active zones," Neuron, vol. 17, no. 4, pp. 617-626, 1996.

[39] I. Antonov, S. Chang, S. Zakharenko, and S. V. Popov, "Distribution of neurotransmitter secretion in growing axons," Neuroscience, vol. 90, no. 3, pp. 975-984, 1999.

[40] S. Zakharenko, S. H. Chang, M. O'Donoghue, and S. V. Popov, "Neurotransmitter secretion along growing nerve processes: comparison with synaptic vesicle exocytosis," The Journal of Cell Biology, vol. 144, no. 3, pp. 507-518, 1999. 
[41] W. D. Yao, J. Rusch, M. M. Poo, and C. F. Wu, "Spontaneous acetylcholine secretion from developing growth cones of Drosophila central neurons in culture: effects of cAMP-pathway mutations," Journal of Neuroscience, vol. 20, no. 7, pp. 2626-2637, 2000.

[42] E. Takao-Rikitsu, S. Mochida, E. Inoue et al., "Physical and functional interaction of the active zone proteins, CAST, RIM1, and Bassoon, in neurotransmitter release," The Journal of Cell Biology, vol. 164, no. 2, pp. 301-311, 2004.

[43] R. W. Burry, "Presynaptic elements on artificial surfaces. A model for the study of development and regeneration of synapses," Neurochemical Pathology, vol. 5, no. 3, pp. 345360, 1986.

[44] M. J. Anderson, S. Champaneria, and L. E. Swenarchuk, "Synaptic differentiation can be evoked by polymer microbeads that mimic localized pericellular proteolysis by removing proteins from adjacent surfaces," Developmental Biology, vol. 147, no. 2, pp. 464-479, 1991.

[45] Z. S. Dai and H. B. Peng, "Presynaptic differentiation induced in cultured neurons by local application of basic fibroblast growth factor," Journal of Neuroscience, vol. 15, no. 8, pp. 5466-5475, 1995.

[46] D. A. DiGregorio, O. Negrete, A. Jeromin, H. B. Peng, and J. L. Vergara, "Contact-dependent aggregation of functional $\mathrm{Ca}^{2+}$ channels, synaptic vesicles and postsynaptic receptors in active zones of a neuromuscular junction," European Journal of Neuroscience, vol. 14, no. 3, pp. 533-546, 2001.

[47] K. Shen and C. I. Bargmann, "The immunoglobulin superfamily protein SYG-1 determines the location of specific synapses in C. elegans," Cell, vol. 112, no. 5, pp. 619-630, 2003.

[48] H. Nishiyama, M. Fukaya, M. Watanabe, and D. J. Linden, "Axonal motility and its modulation by activity are branchtype specific in the intact adult cerebellum," Neuron, vol. 56, no. 3, pp. 472-487, 2007.

[49] D. G. Amaral and J. A. Dent, "Development of the mossy fibers of the dentate gyrus: I. A light and electron microscopic study of the mossy fibers and their expansions," The Journal of Comparative Neurology, vol. 195, no. 1, pp. 51-86, 1981.

[50] D. D. Stettler, H. Yamahachi, W. Li, W. Denk, and C. D. Gilbert, "Axons and synaptic boutons are highly dynamic in adult visual cortex," Neuron, vol. 49, no. 6, pp. 877-887, 2006.

[51] P. G. Haydon and S. B. Kater, "The differential regulation of formation of chemical and electrical connections in Helisoma," Journal of Neurobiology, vol. 19, no. 7, pp. 636-655, 1988.

[52] P. G. Haydon and P. Drapeau, "From contact to connection: early events during synaptogenesis," Trends in Neurosciences, vol. 18, no. 4, pp. 196-201, 1995.

[53] Y. Hatada, F. Wu, R. Silverman, S. Schacher, and D. J. Goldberg, "En passant synaptic varicosities form directly from growth cones by transient cessation of growth cone advance but not of actin-based motility," Journal of Neurobiology, vol. 41, pp. 242-251, 1999.

[54] G. Malkinson, Z. M. Fridman, D. Kamber, A. Dormann, E. Shapira, and M. E. Spira, "Calcium-induced exocytosis from actomyosin-driven, motile varicosities formed by dynamic clusters of organelles," Brain Cell Biology, vol. 35, no. 1, pp. 57-73, 2006.

[55] G. Malkinson and M. E. Spira, "Clustering of excess growth resources within leading growth cones underlies the recurrent "deposition" of varicosities along developing neurites," Experimental Neurology, vol. 225, no. 1, pp. 140-153, 2010.
[56] S. E. Ahmari, J. Buchanan, and S. J. Smith, "Assembly of presynaptic active zones from cytoplasmic transport packets," Nature Neuroscience, vol. 3, no. 5, pp. 445-451, 2000.

[57] E. Koenig, S. Kinsman, E. Repasky, and L. Sultz, "Rapid mobility of motile varicosities and inclusions containing $\alpha$ spectrin, actin, and calmodulin in regeneratig axons in vitro," Journal of Neuroscience, vol. 5, no. 3, pp. 715-729, 1985.

[58] G. M. G. Shepherd and K. M. Harris, "Three-dimensional structure and composition of $\mathrm{CA} 3 \rightarrow \mathrm{CA} 1$ axons in rat hippocampal slices: implications for presynaptic connectivity and compartmentalization," Journal of Neuroscience, vol. 18, no. 20, pp. 8300-8310, 1998.

[59] T. C. Sudhof, A. J. Czernik, H. T. Kao et al., "Synapsins: mosaics of shared and individual domains in a family of synaptic vesicle phosphoproteins," Science, vol. 245, no. 4925, pp. 1474-1480, 1989.

[60] B. Porton, T. T. Kao, and P. Greengard, "Characterization of transcripts from the synapsin III gene locus," Journal of Neurochemistry, vol. 73, no. 6, pp. 2266-2271, 1999.

[61] H. T. Kao, B. Porton, S. Hilfiker et al., "Molecular evolution of the synapsin gene family," Journal of Experimental Zoology, vol. 285, pp. 360-377, 1999.

[62] F. Cesca, P. Baldelli, F. Valtorta, and F. Benfenati, "The synapsins: key actors of synapse function and plasticity," Progress in Neurobiology, vol. 91, no. 4, pp. 313-348, 2010.

[63] Y. Humeau, S. Candiani, M. Ghirardi, B. Poulain, and P. Montarolo, "Functional roles of synapsin: lessons from invertebrates," Seminars in Cell \& Developmental Biology, vol. 22, pp. 425-433, 2011.

[64] P. De Camilli, S. M. Harris, W. B. Huttner, and P. Greengard, "Synapsin I (Protein I), a nerve terminal-specific phosphoprotein. II. Its specific association with synaptic vesicles demonstrated by immunocytochemistry in agarose-embedded synaptosomes," The Journal of Cell Biology, vol. 96, no. 5, pp. 1355-1373, 1983.

[65] T. Ueda and P. Greengard, “Adenosine 3' : 5' monophosphate regulated phosphoprotein system of neuronal membranes. II. Solubilization, purification, and some properties of an endogenous phosphoprotein," Journal of Biological Chemistry, vol. 252, no. 14, pp. 5155-5163, 1977.

[66] F. Benfenati, P. Neyroz, M. Bahler, L. Masotti, and P. Greengard, "Time-resolved fluorescence study of the neuronspecific phosphoprotein synapsin I. Evidence for phosphorylation-dependent conformational changes," Journal of Biological Chemistry, vol. 265, no. 21, pp. 12584-12595, 1990.

[67] P. Chi, P. Greengard, and T. A. Ryan, "Synapsin dispersion and reclustering during synaptic activity," Nature Neuroscience, vol. 4, no. 12, pp. 1187-1193, 2001.

[68] P. Greengard, F. Valtorta, A. J. Czernik, and F. Benfenati, "Synaptic vesicle phosphoproteins and regulation of synaptic function," Science, vol. 259, no. 5096, pp. 780-785, 1993.

[69] T. C. Sudhof, A. J. Czernik, H. T. Kao et al., "Synapsins: mosaics of shared and individual domains in a family of synaptic vesicle phosphoproteins," Science, vol. 245, no. 4925, pp. 1474-1480, 1989.

[70] B. R. E. Klagges, G. Heimbeck, T. A. Godenschwege et al., "Invertebrate synapsins: a single gene codes for several isoforms in Drosophila," Journal of Neuroscience, vol. 16, no. 10, pp. 3154-3165, 1996.

[71] S. Hilfiker, F. E. Schweizer, H. T. Kao, A. J. Czernik, P. Greengard, and G. J. Augustine, "Two sites of action for synapsin domain E in regulating neurotransmitter release," $\mathrm{Na}$ ture Neuroscience, vol. 1, no. 1, pp. 29-35, 1998. 
[72] A. Angers, D. Fioravante, J. Chin, L. J. Cleary, A. J. Bean, and J. H. Byrne, "Serotonin stimulates phosphorylation of Aplysia synapsin and alters its subcellular distribution in sensory neurons," Journal of Neuroscience, vol. 22, no. 13, pp. 5412 5422, 2002.

[73] F. Fiumara, C. Milanese, A. Corradi et al., "Phosphorylation of synapsin domain A is required for post-tetanic potentiation," Journal of Cell Science, vol. 120, no. 18, pp. 3228-3237, 2007.

[74] I. L. Bogen, V. Jensen, O. Hvalby, and S. I. Walaas, "Synapsindependent development of glutamatergic synaptic vesicles and presynaptic plasticity in postnatal mouse brain," Neuroscience, vol. 158, no. 1, pp. 231-241, 2009.

[75] A. Ferreira, H. T. Kao, J. Feng, M. Rapoport, and P. Greengard, "Synapsin III: developmental expression, subcellular localization, and role in axon formation," Journal of Neuroscience, vol. 20, no. 10, pp. 3736-3744, 2000.

[76] B. Lu, A. J. Czernik, S. Popov, T. Wang, M. M. Poo, and P. Greengard, "Expression of synapsin I correlates with maturation of the neuromuscular synapse," Neuroscience, vol. 74, no. 4, pp. 1087-1097, 1996.

[77] B. Lu, P. Greengard, and M. M. Poo, "Exogenous synapsin I promotes functional maturation of developing neuromuscular synapses," Neuron, vol. 8, no. 3, pp. 521-529, 1992.

[78] E. Schaeffer, J. Alder, P. Greengard, and M. M. Poo, "Synapsin IIa accelerates functional development of neuromuscular synapses," Proceedings of the National Academy of Sciences of the United States of America, vol. 91, no. 9, pp. 3882-3886, 1994.

[79] F. Valtorta, N. Lezzi, F. Benfenati, B. Lu, M. M. Poo, and P. Greengard, "Accelerated structural maturation induced by synapsin I at developing neuromuscular synapses of Xenopus laevis," European Journal of Neuroscience, vol. 7, no. 2, pp. 261-270, 1995.

[80] H. Q. Han, R. A. Nichols, M. R. Rubin, M. Bahler, and P. Greengard, "Induction of formation of presynaptic terminals in neuroblastoma cells by synapsin IIB," Nature, vol. 349, no. 6311, pp. 697-700, 1991.

[81] T. L. Fletcher, P. Cameron, P. De Camilli, and G. Banker, "The distribution of synapsin I and synaptophysin in hippocampal neurons developing in culture," Journal of Neuroscience, vol. 11, no. 6, pp. 1617-1626, 1991.

[82] J. Chin, A. Angers, L. J. Cleary, A. Eskin, and J. H. Byrne, "Transforming growth factor betal alters synapsin distribution and modulates synaptic depression in Aplysia," Journal of Neuroscience, vol. 22, no. 9, Article ID RC220, 2002.

[83] J. Camardo, E. Proshansky, and S. Schacher, "Identified Aplysia neurons form specific chemical synapses in culture," Journal of Neuroscience, vol. 3, no. 12, pp. 2614-2620, 1983.

[84] H. Arechiga, M. Chiquet, D. P. Kuffler, and J. G. Nicholls, "Formation of specific connections in culture by identified leech neurons containing serotonin, acetylcholine and peptide transmitters," Journal of Experimental Biology, vol. 126, pp. 15-31, 1986.

[85] L. Vyklicky and J. Nicholls, "Specificity of connections formed by nociceptive cells of the leech in tissue-culture," Journal of Experimental Biology, vol. 134, pp. 17-26, 1988.

[86] G. M. Carrow and I. B. Levitan, "Selective formation and modulation of electrical synapses between cultured Aplysia neurons," Journal of Neuroscience, vol. 9, no. 10, pp. 36573664, 1989.

[87] N. I. Syed and G. E. Spencer, "Target-cell selection and specific synapse formation by identified Lymnaea neurons in vitro," Netherlands Journal of Zoology, vol. 44, pp. 327-338, 1994.

[88] M. J. Zoran, R. T. Doyle, and P. G. Haydon, "Targetdependent induction of secretory capabilities in an identified motoneuron during synaptogenesis," Developmental Biology, vol. 138, no. 1, pp. 202-213, 1990.

[89] K. R. Weiss and I. Kupfermann, "Homology of the giant serotonergic neurons (metacerebral cells) in Aplysia and pulmonate molluscs," Brain Research, vol. 117, no. 1, pp. 33-49, 1976.

[90] G. A. Cottrell and J. B. Macon, "Synaptic connexions of two symmetrically placed giant serotonin containing neurones," Journal of Physiology, vol. 236, no. 2, pp. 435-464, 1974.

[91] M. Ghirardi, A. Casadio, G. Naretto, R. Levi, and P. G. Montarolo, "Influence of the target on distribution and functioning of the varicosities of Helix pomatia metacerebral cell C1 in dissociated cell culture," Neuroscience, vol. 96, no. 4, pp. 843-853, 2000.

[92] M. Ghirardi, F. Benfenati, S. Giovedi, F. Fiumara, C. Milanese, and P. G. Montarolo, "Inhibition of neurotransmitter release by a nonphysiological target requires protein synthesis and involves cAMP-dependent and mitogen-activated protein kinases," Journal of Neuroscience, vol. 24, no. 21, pp. 5054-5062, 2004.

[93] F. Fiumara, F. Onofri, F. Benfenati, P. G. Montarolo, and M. Ghirardi, "Intracellular injection of synapsin I induces neurotransmitter release in $\mathrm{C} 1$ neurons of Helix pomatia contacting a wrong target," Neuroscience, vol. 104, no. 1, pp. 271-280, 2001.

[94] F. Fiumara, S. Giovedi, A. Menegon et al., "Phosphorylation by cAMP-dependent protein kinase is essential for synapsininduced enhancement of neurotransmitter release in invertebrate neurons," Journal of Cell Science, vol. 117, no. 21, pp. 5145-5154, 2004.

[95] C. N. G. Giachello, F. Fiumara, C. Giacomini et al., "MAPK/Erk-dependent phosphorylation of synapsin mediates formation of functional synapses and short-term homosynaptic plasticity," Journal of Cell Science, vol. 123, no. 6, pp. 881-893, 2010.

[96] D. Bonanomi, A. Menegon, A. Miccio et al., "Phosphorylation of synapsin I by cAMP-dependent protein kinase controls synaptic vesicle dynamics in developing neurons," Journal of Neuroscience, vol. 25, no. 32, pp. 7299-7308, 2005.

[97] L. R. Funte and P. G. Haydon, "Synaptic target contact enhances presynaptic calcium influx by activating cAMP-dependent protein kinase during synaptogenesis," Neuron, vol. 10, no. 6, pp. 1069-1078, 1993.

[98] L. E. Perlini, F. Botti, E. F. Fornasiero et al., "Effects of phosphorylation and neuronal activity on the control of synapse formation by synapsin I," Journal of Cell Science, vol. 124, pp. 3643-3653, 2011.

[99] A. Martinez, S. Alcantara, V. Borrell et al., "TrkB and TrkC signaling are required for maturation and synaptogenesis of hippocampal connections," Journal of Neuroscience, vol. 18, no. 18, pp. 7336-7350, 1998.

[100] C. Vicario-Abejon, C. Collin, R. D. G. McKay, and M. Segal, "Neurotrophins induce formation of functional excitatory and inhibitory synapses between cultured hippocampal neurons," Journal of Neuroscience, vol. 18, no. 18, pp. 7256-7271, 1998.

[101] C. Vicario-Abejon, D. Owens, R. McKay, and M. Segal, "Role of neurotrophins in central synapse formation and stabilization," Nature Reviews Neuroscience, vol. 3, no. 12, pp. 965974, 2002. 
[102] C. Collin, C. Vicario-Abejon, M. E. Rubio, R. J. Wenthold, R. D. G. McKay, and M. Segal, "Neurotrophins act at presynaptic terminals to activate synapses among cultured hippocampal neurons," European Journal of Neuroscience, vol. 13, no. 7, pp. 1273-1282, 2001.

[103] W. J. Tyler and L. D. Pozzo-Miller, "BDNF enhances quantal neurotransmitter release and increases the number of docked vesicles at the active zones of hippocampal excitatory synapses," Journal of Neuroscience, vol. 21, no. 12, pp. 42494258, 2001.

[104] M. Alonso, J. H. Medina, and L. Pozzo-Miller, "ERK1/2 activation is necessary for BDNF to increase dendritic spine density in hippocampal CA1 pyramidal neurons," Learning and Memory, vol. 11, no. 2, pp. 172-178, 2004.

[105] J. N. Jovanovic, F. Benfenati, Y. L. Siow et al., "Neurotrophins stimulate phosphorylation of synapsin I by MAP kinase and regulate synapsin I-actin interactions," Proceedings of the National Academy of Sciences of the United States of America, vol. 93, no. 8, pp. 3679-3683, 1996.

[106] D. Gitler, Y. Xu, H. T. Kao et al., "Molecular determinants of synapsin targeting to presynaptic terminals," Journal of Neuroscience, vol. 24, no. 14, pp. 3711-3720, 2004.

[107] M. Hosaka, R. E. Hammer, and T. C. Sudhof, "A phosphoswitch controls the dynamic association of synapsins with synaptic vesicles,” Neuron, vol. 24, no. 2, pp. 377-387, 1999.

[108] P. Chi, P. Greengard, and T. A. Ryan, "Synaptic vesicle mobilization is regulated by distinct synapsin I phosphorylation pathways at different frequencies," Neuron, vol. 38, no. 1, pp. 69-78, 2003.

[109] Y. Humeau, F. Doussau, F. Vitiello, P. Greengard, F. Benfenati, and B. Poulain, "Synapsin controls both reserve and releasable synaptic vesicle pools during neuronal activity and short-term plasticity in Aplysia," Journal of Neuroscience, vol. 21, no. 12, pp. 4195-4206, 2001.

[110] M. A. Cousin, C. S. Malladi, T. C. Tan, C. R. Raymond, K. J. Smillie, and P. J. Robinson, "Synapsin I-associated phosphatidylinositol 3-kinase mediates synaptic vesicle delivery to the readily releasable pool," Journal of Biological Chemistry, vol. 278, no. 31, pp. 29065-29071, 2003.

[111] S. Giovedi, P. Vaccaro, F. Valtorta et al., "Synapsin is a novel Rab3 effector protein on small synaptic vesicles: I. Identification and characterization of the synapsin I-Rab3 interactions in vitro and in intact nerve terminals," Journal of Biological Chemistry, vol. 279, no. 42, pp. 43760-43768, 2004.

[112] T. W. Rosahl, D. Spillane, M. Missler et al., "Essential functions of synapsins I and II in synaptic vesicle regulation," $\mathrm{Na}$ ture, vol. 375, no. 6531, pp. 488-493, 1995.

[113] H. Kuromi and Y. Kidokoro, "Selective replenishment of two vesicle pools depends on the source of $\mathrm{Ca}^{2+}$ at the Drosophila synapse," Neuron, vol. 35, no. 2, pp. 333-343, 2002.

[114] Y. Kidokoro, H. Kuromi, R. Delgado, C. Maureira, C. Oliva, and P. Labarca, "Synaptic vesicle pools and plasticity of synaptic transmission at the Drosophila synapse," Brain Research Reviews, vol. 47, no. 1-3, pp. 18-32, 2004.

[115] R. L. P. Habets and J. G. G. Borst, "Post-tetanic potentiation in the rat calyx of Held synapse," Journal of Physiology, vol. 564, no. 1, pp. 173-187, 2005.

[116] J. Y. Sun, P. Bronk, X. Liu, W. Han, and T. C. Sudhof, "Synapsins regulate use-dependent synaptic plasticity in the calyx of Held by a $\mathrm{Ca}^{2+} /$ calmodulin-dependent pathway," Proceedings of the National Academy of Sciences of the United States of America, vol. 103, no. 8, pp. 2880-2885, 2006.

[117] S. Hilfiker, F. D. R. Benfenati, F. Doussau et al., "Structural domains involved in the regulation of transmitter release by synapsins," Journal of Neuroscience, vol. 25, no. 10, pp. 26582669, 2005.

[118] F. Doussau, Y. Humeau, F. Benfenati, and B. Poulain, "A novel form of presynaptic plasticity based on the fast reactivation of release sites switched off during low-frequency depression," Journal of Neuroscience, vol. 30, no. 49, pp. 16679-16691, 2010.

[119] S. Impey, K. Obrietan, and D. R. Storm, "Making new connections: role of ERK/MAP kinase signaling in neuronal plastic0ity," Neuron, vol. 23, no. 1, pp. 11-14, 1999.

[120] N. Agell, O. Bachs, N. Rocamora, and P. Villalonga, "Modulation of the Ras/Raf/MEK/ERK pathway by $\mathrm{Ca}^{2+}$, and Calmodulin," Cellular Signalling, vol. 14, no. 8, pp. 649-654, 2002.

[121] T. R. Soderling, "The $\mathrm{Ca}^{2+}$-calmodulin-dependent protein kinase cascade," Trends in Biochemical Sciences, vol. 24, no. 6, pp. 232-236, 1999.

[122] G. D. Ferguson and D. R. Storm, "Why calcium-stimulated adenylyl cyclases?” Physiology, vol. 19, no. 5, pp. 271-276, 2004.

[123] Y. D. Shaul and R. Seger, "The MEK/ERK cascade: from signaling specificity to diverse functions," Biochimica et Biophysica Acta, vol. 1773, no. 8, pp. 1213-1226, 2007.

[124] N. Gerits, S. Kostenko, A. Shiryaev, M. Johannessen, and U. Moens, "Relations between the mitogen-activated protein kinase and the cAMP-dependent protein kinase pathways: comradeship and hostility," Cellular Signalling, vol. 20, no. 9, pp. 1592-1607, 2008.

[125] A. L. Purcell, S. K. Sharma, M. W. Bagnall, M. A. Sutton, and T. J. Carew, "Activation of a tyrosine kinase-MAPK cascade enhances the induction of long-term synaptic facilitation and long-term memory in Aplysia," Neuron, vol. 37, no. 3, pp. 473-484, 2003.

[126] G. A. Phares and J. H. Byrne, "Analysis of 5-HT-induced short-term facilitation at Aplysia sensorimotor synapse during bursts: increased synaptic gain that does not require ERK activation," Journal of Neurophysiology, vol. 94, no. 1, pp. 871-877, 2005.

[127] V. Tancredi, M. D’Antuono, C. Cafe et al., "The inhibitory effects of interleukin-6 on synaptic plasticity in the rat hippocampus are associated with an inhibition of mitogenactivated protein kinase ERK," Journal of Neurochemistry, vol. 75, no. 2, pp. 634-643, 2000.

[128] M. Roberto, T. E. Nelson, C. L. Ur, M. Brunelli, P. P. Sanna, and D. L. Gruol, "The transient depression of hippocampal CA1 LTP induced by chronic intermittent ethanol exposure is associated with an inhibition of the MAP kinase pathway," European Journal of Neuroscience, vol. 17, no. 8, pp. 16461654, 2003.

[129] A. Khoutorsky and M. E. Spira, "Activity-dependent calpain activation plays a critical role in synaptic facilitation and post-tetanic potentiation," Learning and Memory, vol. 16, no. 2, pp. 129-141, 2009.

[130] S. A. Kushner, Y. Elgersma, G. G. Murphy et al., "Modulation of presynaptic plasticity and learning by the $\mathrm{H}$ ras/extracellular signal-regulated kinase/synapsin I signaling pathway," Journal of Neuroscience, vol. 25, no. 42, pp. 97219734, 2005.

[131] G. S. Marrs, S. H. Green, and M. E. Dailey, "Rapid formation and remodeling of postsynaptic densities in developing dendrites," Nature Neuroscience, vol. 4, no. 10, pp. 1006-1013, 2001. 
[132] J. E. Vaughn, "Fine structure of synaptogenesis in the vertebrate central nervous system," Synapse, vol. 3, no. 3, pp. 255285, 1989.

[133] N. E. Ziv and S. J. Smith, "Evidence for a role of dendritic filopodia in synaptogenesis and spine formation," Neuron, vol. 17, no. 1, pp. 91-102, 1996.

[134] F. Engert and T. Bonhoeffer, "Dendritic spine changes associated with hippocampal long-term synaptic plasticity," Nature, vol. 399, no. 6731, pp. 66-70, 1999.

[135] P. Jourdain, K. Fukunaga, and D. Muller, "Calcium/calmodulin-dependent protein kinase II contributes to activitydependent filopodia growth and spine formation," Journal of Neuroscience, vol. 23, no. 33, pp. 10645-10649, 2003.

[136] C. Sotelo, "Purkinje cell ontogeny: formation and maintenance of spines," Progress in Brain Research, vol. 48, pp. 149170, 1978.

[137] C. Sotelo, "Cerebellar synaptogenesis: what we can learn from mutant mice," Journal of Experimental Biology, vol. 153, pp. 225-249, 1990.

[138] R. Yuste and T. Bonhoeffer, "Genesis of dendritic spines: insights from ultrastructural and imaging studies," Nature Reviews Neuroscience, vol. 5, no. 1, pp. 24-34, 2004.

[139] M. De Roo, P. Klauser, P. Mendez, L. Poglia, and D. Muller, "Activity-dependent PSD formation and stabilization of newly formed spines in hippocampal slice cultures," Cerebral Cortex, vol. 18, no. 1, pp. 151-161, 2008.

[140] G. W. Knott, A. Holtmaat, L. Wilbrecht, E. Welker, and K. Svoboda, "Spine growth precedes synapse formation in the adult neocortex in vivo," Nature Neuroscience, vol. 9, no. 9, pp. 1117-1124, 2006.

[141] R. Cesa and P. Strata, "Activity-dependent axonal and synaptic plasticity in the cerebellum," Psychoneuroendocrinology, vol. 32, no. 1, pp. S31-S35, 2007.

[142] R. Cesa and P. Strata, "Axonal competition in the synaptic wiring of the cerebellar cortex during development and in the mature cerebellum," Neuroscience, vol. 162, no. 3, pp. 624$632,2009$.

[143] J. R. Sanes and J. W. Lichtman, "Development of the vertebrate neuromuscular junction," Annual Review of Neuroscience, vol. 22, pp. 389-442, 1999.

[144] T. Nguyen and T. C. Sudhof, "Binding properties of neuroligin 1 and neurexin $1 \beta$ reveal function as heterophilic cell adhesion molecules," Journal of Biological Chemistry, vol. 272, no. 41, pp. 26032-26039, 1997.

[145] M. A. Takasu, M. B. Dalva, R. E. Zigmond, and M. E. Greenberg, "Modulation of NMDA receptor-dependent calcium influx and gene expression through EphB receptors," Science, vol. 295, no. 5554, pp. 491-495, 2002.

[146] J. L. Bruses, "Cadherin-mediated adhesion at the interneuronal synapse," Current Opinion in Cell Biology, vol. 12, no. 5, pp. 593-597, 2000.

[147] A. M. Fannon and D. R. Colman, "A model for central synaptic junctional complex formation based on the differential adhesive specificities of the cadherins," Neuron, vol. 17, no. 3, pp. 423-434, 1996.

[148] L. Shapiro and D. R. Colman, "The diversity of cadherins and implications for a synaptic adhesive code in the CNS," Neuron, vol. 23, no. 3, pp. 427-430, 1999.

[149] Y. Takai, K. Shimizu, and T. Ohtsuka, "The roles of cadherins and nectins in interneuronal synapse formation," Current Opinion in Neurobiology, vol. 13, no. 5, pp. 520-526, 2003.

[150] N. Uchida, Y. Honjo, K. R. Johnson, M. J. Wheelock, and M. Takeichi, "The catenin/cadherin adhesion system is localized in synaptic junctions bordering transmitter release zones," The Journal of Cell Biology, vol. 135, no. 3, pp. 767-779, 1996.

[151] T. Uemura, "The cadherin superfamily at the synapse: more members, more missions," Cell, vol. 93, no. 7, pp. 1095-1098, 1998.

[152] T. Yagi and M. Takeichi, "Cadherin superfamily genes: functions, genomic organization, and neurologic diversity," Genes and Development, vol. 14, no. 10, pp. 1169-1180, 2000.

[153] D. L. Benson and H. Tanaka, "N-cadherin redistribution during synaptogenesis in hippocampal neurons," Journal of Neuroscience, vol. 18, no. 17, pp. 6892-6904, 1998.

[154] H. Togashi, K. Abe, A. Mizoguchi, K. Takaoka, O. Chisaka, and M. Takeichi, "Cadherin regulates dendritic spine morphogenesis," Neuron, vol. 35, no. 1, pp. 77-89, 2002.

[155] Y. Iwai, T. Usui, S. Hirano, R. Steward, M. Takeichi, and T. Uemura, "Axon patterning requires DN-cadherin, a novel neuronal adhesion receptor, in the Drosophila embryonic CNS," Neuron, vol. 19, no. 1, pp. 77-89, 1997.

[156] C. H. Lee, T. Herman, T. R. Clandinin, R. Lee, and S. L. Zipursky, "N-cadherin regulates target specificity in the Drosophila visual system," Neuron, vol. 30, no. 2, pp. 437-450, 2001.

[157] A. Nern, L. V. T. Nguyen, T. Herman, S. Prakash, T. R. Clandinin, and S. L. Zipursky, "An isoform-specific allele of Drosophila N-cadherin disrupts a late step of R7 targeting," Proceedings of the National Academy of Sciences of the United States of America, vol. 102, no. 36, pp. 12944-12949, 2005.

[158] A. Nern, Y. Zhu, and S. L. Zipursky, "Local N-cadherin interactions mediate distinct steps in the targeting of lamina neurons," Neuron, vol. 58, no. 1, pp. 34-41, 2008.

[159] C. Y. Ting, S. Yonekura, P. Chung et al., "Drosophila Ncadherin functions in the first stage of the two-stage layerselection process of R7 photoreceptor afferents," Development, vol. 132, no. 5, pp. 953-963, 2005.

[160] R. D. Fields and K. Itoh, "Neural cell adhesion molecules in activity-dependent development and synaptic plasticity," Trends in Neurosciences, vol. 19, no. 11, pp. 473-480, 1996.

[161] A. Luthl, J. P. Laurent, A. Figurov, D. Muller, and M. Schachner, "Hippocampal long-term potentiation and pleural cell adhesion molecules L1 and NCAM," Nature, vol. 372, pp. 777-779, 1994.

[162] E. Persohn, G. E. Pollerberg, and M. Schachner, "Immunoelectron-microscopic localization of the $180 \mathrm{kD}$ component of the neural cell adhesion molecule N-CAM in postsynaptic membranes," The Journal of Comparative Neurology, vol. 288, no. 1, pp. 92-100, 1989.

[163] E. Persohn and M. Schachner, "Immunohistological localization of the neural adhesion molecules L1 and N-CAM in the developing hippocampus of the mouse," Journal of Neurocytology, vol. 19, no. 6, pp. 807-819, 1990.

[164] T. Schuster, M. Krug, M. Stalder, N. Hackel, R. GerardySchahn, and M. Schachner, "Immunoelectron microscopic localization of the neural recognition molecules L1, NCAM, and its isoform NCAM180, the NCAM-associated polysialic acid, betal integrin and the extracellular matrix molecule tenascin-R in synapses of the adult rat hippocampus," Journal of Neurobiology, vol. 49, no. 2, pp. 142-158, 2001.

[165] G. Rougon and O. Hobert, "New insights into the diversity and function of neuronal immunoglobulin superfamily molecules," Annual Review of Neuroscience, vol. 26, pp. 207-238, 2003.

[166] M. Schachner, "Neural recognition molecules and synaptic plasticity," Current Opinion in Cell Biology, vol. 9, no. 5, pp. 627-634, 1997. 
[167] V. Sytnyk, I. Leshchyns'ka, M. Delling, G. Dityateva, A. Dityatev, and M. Schachner, "Neural cell adhesion molecule promotes accumulation of TGN organelles at sites of neuronto-neuron contacts.," The Journal of Cell Biology, vol. 159, no. 4, pp. 649-661, 2002.

[168] V. Sytnyk, I. Leshchyns'ka, A. Dityatev, and M. Schachner, "Trans-Golgi network delivery of synaptic proteins in synaptogenesis," Journal of Cell Science, vol. 117, no. 3, pp. 381-388, 2004.

[169] V. Sytnyk, I. Leshchyns'Ka, A. G. Nikonenko, and M. Schachner, "NCAM promotes assembly and activity-dependent remodeling of the postsynaptic signaling complex," The Journal of Cell Biology, vol. 174, no. 7, pp. 1071-1085, 2006.

[170] A. Dityatev, G. Dityateva, and M. Schachner, "Synaptic strength as a function of post-versus presynaptic expression of the neural cell adhesion molecule NCAM," Neuron, vol. 26, no. 1, pp. 207-217, 2000.

[171] V. Budnik, Y. Zhong, and C. F. Wu, "Morphological plasticity of motor axons in Drosophila mutants with altered excitability," Journal of Neuroscience, vol. 10, no. 11, pp. 3754-3768, 1990.

[172] M. Mayford, A. Barzilai, F. Keller, S. Schacher, and E. R. Kandel, "Modulation of an NCAM-related adhesion molecule with long-term synaptic plasticity in Aplysia," Science, vol. 256, no. 5057, pp. 638-644, 1992.

[173] Y. Zhong, V. Budnik, and C. F. Wu, "Synaptic plasticity in Drosophila memory and hyperexcitable mutants: role of cAMP cascade," Journal of Neuroscience, vol. 12, no. 2, pp. 644-651, 1992.

[174] C. H. Bailey and E. R. Kandel, "Structural changes accompanying memory storage," Annual Review of Physiology, vol. 55, pp. 397-426, 1993.

[175] J. Q. Davis, S. Lambert, and V. Bennett, "Molecular composition of the node of Ranvier: identification of ankyrinbinding cell adhesion molecules neurofascin (Mucin+/third FNIII domain-) and NrCAM at nodal axon segments," The Journal of Cell Biology, vol. 135, no. 5, pp. 1355-1367, 1996.

[176] D. Muller, C. Wang, G. Skibo et al., "PSA-NCAM is required for activity-induced synaptic plasticity," Neuron, vol. 17, no. 3, pp. 413-422, 1996.

[177] C. M. Schuster, G. W. Davis, R. D. Fetter, and C. S. Goodman, "Genetic dissection of structural and functional components of synaptic plasticity. I. Fasciclin II controls synaptic stabilization and growth," Neuron, vol. 17, no. 4, pp. 641-654, 1996.

[178] C. M. Schuster, G. W. Davis, R. D. Fetter, and C. S. Goodman, "Genetic dissection of structural and functional components of synaptic plasticity. II. Fasciclin II controls presynaptic structural plasticity," Neuron, vol. 17, no. 4, pp. 655-667, 1996.

[179] C. H. Bailey, B. K. Kaang, M. Chen et al., "Mutation in the phosphorylation sites of MAP kinase blocks learning- related internalization of apCAM in Aplysia sensory neurons," Neuron, vol. 18, no. 6, pp. 913-924, 1997.

[180] I. Chow, "Cell-cell interaction during synaptogenesis," Journal De Physiologie, vol. 84, no. 1, pp. 121-127, 1990.

[181] F. Keller and S. Schacher, "Neuron-specific membrane glycoproteins promoting neurite fasciculation in Aplysia californica," The Journal of Cell Biology, vol. 111, no. 6, pp. 26372650, 1990.

[182] C. H. Bailey, M. Chen, F. Keller, and E. R. Kandel, "Serotoninmediated endocytosis of apCAM: an early step of learningrelated synaptic growth in Aplysia," Science, vol. 256, no. 5057, pp. 645-649, 1992.
[183] F. Wu and S. Schacher, "Presynaptic and postsynaptic changes mediated by two second messengers contribute to expression of Aplysia long-term heterosynaptic inhibition," Neuron, vol. 12, no. 2, pp. 407-421, 1994.

[184] H. Zhu, F. Wu, and S. Schacher, "Aplysia cell adhesion molecules and serotonin regulate sensory cell-motor cell interactions during early stages of synapse formation in vitro," Journal of Neuroscience, vol. 14, no. 11, pp. 6886-6900, 1994.

[185] H. Zhu, F. Wu, and S. Schacher, "Changes in expression and distribution of Aplysia cell adhesion molecules can influence synapse formation and elimination in vitro," Journal of Neuroscience, vol. 15, no. 6, pp. 4173-4183, 1995.

[186] S. Schacher, F. Wu, Z. Y. Sun, and D. N. Wang, "Cellspecific changes in expression of mRNAs encoding splice variants of Aplysia cell adhesion molecule accompany longterm synaptic plasticity," Journal of Neurobiology, vol. 45, pp. 152-161, 2000.

[187] N. Peter, B. Aronoff, F. Wu, and S. Schacher, "Decrease in growth cone-neurite fasciculation by sensory or motor cells in vitro accompanies downregulation of Aplysia cell adhesion molecules by neurotransmitters," Journal of Neuroscience, vol. 14, no. 3, pp. 1413-1421, 1994.

[188] M. Ghirardi, G. Naretto, F. Fiumara, F. Vitiello, and P. G. Montarolo, "Target-dependent modulation of neurotransmitter release in cultured Helix neurons involves adhesion molecules," Journal of Neuroscience Research, vol. 65, no. 2, pp. 111-120, 2001.

[189] P. F. Maness and M. Schachner, "Neural recognition molecules of the immunoglobulin superfamily: signaling transducers of axon guidance and neuronal migration," Nature Neuroscience, vol. 10, no. 1, pp. 19-26, 2007.

[190] D. K. Ditlevsen, G. K. Povlsen, V. Berezin, and E. Bock, "NCAM-induced intracellular signaling revisited," Journal of Neuroscience Research, vol. 86, no. 4, pp. 727-743, 2008.

[191] J. Y. Hu, Y. Chen, J. K. Bougie, W. S. Sossin, and S. Schacher, "Aplysia cell adhesion molecule and a novel protein kinase $\mathrm{C}$ activity in the postsynaptic neuron are required for presynaptic growth and initial formation of specific synapses," Journal of Neuroscience, vol. 30, no. 25, pp. 83538366, 2010.

[192] P. Conrad, F. Wu, and S. Schacher, "Changes in functional glutamate receptors on a postsynaptic neuron accompany formation and maturation of an identified synapse," Journal of Neurobiology, vol. 39, pp. 237-248, 1999.

[193] P. Washbourne, A. Dityatev, P. Scheiffele et al., "Cell adhesion molecules in synapse formation," Journal of Neuroscience, vol. 24, no. 42, pp. 9244-9249, 2004.

[194] H. Kohsaka, E. Takasu, and A. Nose, "In vivo induction of postsynaptic molecular assembly by the cell adhesion molecule Fasciclin2," The Journal of Cell Biology, vol. 179, no. 6, pp. 1289-1300, 2007.

[195] D. Cai, S. Chen, and D. L. Glanzman, "Postsynaptic regulation of long-term facilitation in Aplysia," Current Biology, vol. 18, no. 12, pp. 920-925, 2008.

[196] H.-L. Li, B. S. Huang, H. Vishwasrao et al., "Dscam mediates remodeling of glutamate receptors in Aplysia during de novo and learning-related synapse formation," Neuron, vol. 61, no. 4, pp. 527-540, 2009.

[197] G. Villareal, Q. Li, D. Cai et al., "Role of protein kinase C in the induction and maintenance of serotonin-dependent enhancement of the glutamate response in isolated siphon motor neurons of Aplysia californica," Journal of Neuroscience, vol. 29, no. 16, pp. 5100-5107, 2009. 
[198] T. Biederer, Y. Sara, M. Mozhayeva et al., "SynCAM, a synaptic adhesion molecule that drives synapse assembly," Science, vol. 297, no. 5586, pp. 1525-1531, 2002.

[199] T. Shingai, W. Ikeda, S. Kakunaga et al., "Implications of nectin-like molecule-2/IGSF4/RA175/SgIGSF/TSLC1/SynCAM1 in cell-cell adhesion and transmembrane protein localization in epithelial cells," Journal of Biological Chemistry, vol. 278, no. 37, pp. 35421-35427, 2003.

[200] M. Matsuzaki, N. Honkura, G. C. R. Ellis-Davies, and H. Kasai, "Structural basis of long-term potentiation in single dendritic spines," Nature, vol. 429, no. 6993, pp. 761-766, 2004.

[201] A. Holtmaat, L. Wilbrecht, G. W. Knott, E. Welker, and K. Svoboda, "Experience-dependent and cell-type-specific spine growth in the neocortex," Nature, vol. 441, no. 7096, pp. 979-983, 2006.

[202] K. Zito, V. Scheuss, G. Knott, T. Hill, and K. Svoboda, "Rapid functional maturation of nascent dendritic spines," Neuron, vol. 61, no. 2, pp. 247-258, 2009.

[203] N. Honkura, M. Matsuzaki, J. Noguchi, G. C. R. Ellis-Davies, and H. Kasai, "The subspine organization of actin fibers regulates the structure and plasticity of dendritic spines," Neuron, vol. 57, no. 5, pp. 719-729, 2008.

[204] C. D. Harvey and K. Svoboda, "Locally dynamic synaptic learning rules in pyramidal neuron dendrites," Nature, vol. 450, no. 7173, pp. 1195-1200, 2007.

[205] I. Ehrlich, M. Klein, S. Rumpel, and R. Malinow, "PSD95 is required for activity-driven synapse stabilization," Proceedings of the National Academy of Sciences of the United States of America, vol. 104, no. 10, pp. 4176-4181, 2007.

[206] C. D. Kopec, E. Real, H. W. Kessels, and R. Malinow, "GluR1 links structural and functional plasticity at excitatory synapses," Journal of Neuroscience, vol. 27, no. 50, pp. 1370613718, 2007.

[207] C. W. Cotman, N. P. Hailer, K. K. Pfister, I. Soltesz, and M. Schachner, "Cell adhesion molecules in neural plasticity and pathology: similar mechanisms, distinct organizations?" Progress in Neurobiology, vol. 55, no. 6, pp. 659-669, 1998.

[208] H. Cremer, G. Chazal, A. Carleton, C. Goridis, J. D. Vincent, and P. M. Lledo, "Long-term but not short-term plasticity at mossy fiber synapses is impaired in neural cell adhesion molecule-deficient mice," Proceedings of the $\mathrm{Na}$ tional Academy of Sciences of the United States of America, vol. 95, no. 22, pp. 13242-13247, 1998.

[209] J. Z. Kiss and D. Muller, "Contribution of the neural cell adhesion molecule to neuronal and synaptic plasticity," Reviews in the Neurosciences, vol. 12, no. 4, pp. 297-310, 2001.

[210] S. Murase and E. M. Schuman, "The role of cell adhesion molecules in synaptic plasticity and memory," Current Opinion in Cell Biology, vol. 11, no. 5, pp. 549-553, 1999.

[211] L. C. B. Ronn, E. Bock, D. Linnemann, and H. Jahnsen, "NCAM-antibodies modulate induction of long-term potentiation in rat hippocampal CA1," Brain Research, vol. 677, no. 1, pp. 145-151, 1995.

[212] D. L. Glanzman, E. R. Kandel, and S. Schacher, "Targetdependent structural changes accompanying long-term synaptic facilitation in Aplysia neurons," Science, vol. 249, no. 4970, pp. 799-802, 1990.

[213] P. G. Montarolo, E. R. Kandel, and S. Schacher, "Long-term heterosynaptic inhibition in Aplysia," Nature, vol. 333, no. 6169, pp. 171-174, 1988.

[214] S. Schacher and P. G. Montarolo, "Target-dependent structural changes in sensory neurons of Aplysia accompany long-term heterosynaptic inhibition," Neuron, vol. 6, no. 5, pp. 679-690, 1991.

[215] Y. Hu, A. Barzilai, M. Chen, C. H. Bailey, and E. R. Kandel, " 5 -HT and cAMP induce the formation of coated pits and vesicles and increase the expression of clathrin light chain in sensory neurons of Aplysia," Neuron, vol. 10, no. 5, pp. 921929, 1993.

[216] H. Cremer, R. Lange, A. Christoph et al., "Inactivation of the $\mathrm{N}$-CAM gene in mice results in size reduction of the olfactory bulb and deficits in spatial learning," Nature, vol. 367, no. 6462, pp. 455-459, 1994.

[217] C. G. Becker, A. Artola, R. GerardySchahn, T. Decker, H. Welzl, and M. Schachner, "The polysialic acid modification of the neural cell adhesion molecule is involved in spatial learning and hippocampal long-term potentiation," Journal of Neuroscience Research, vol. 45, pp. 143-152, 1996. 

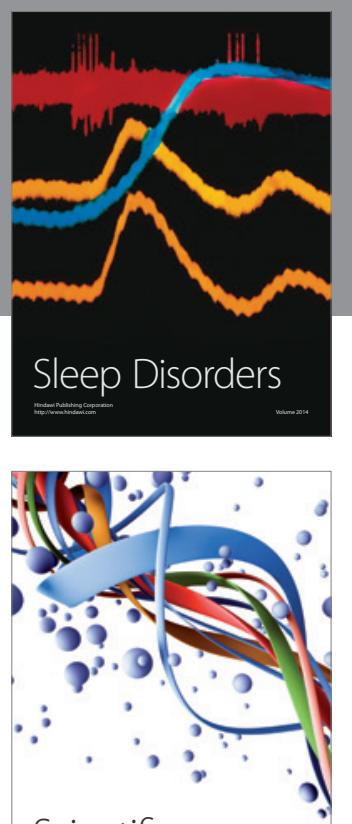

Scientifica
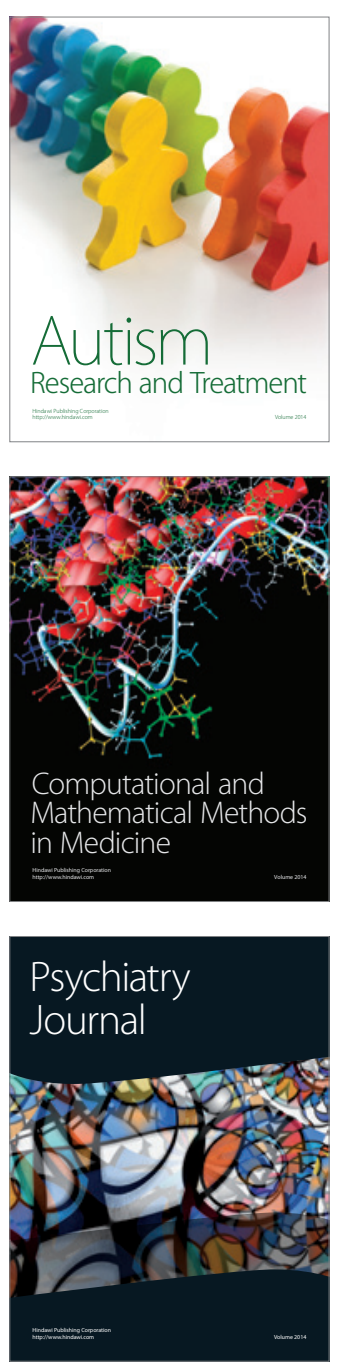
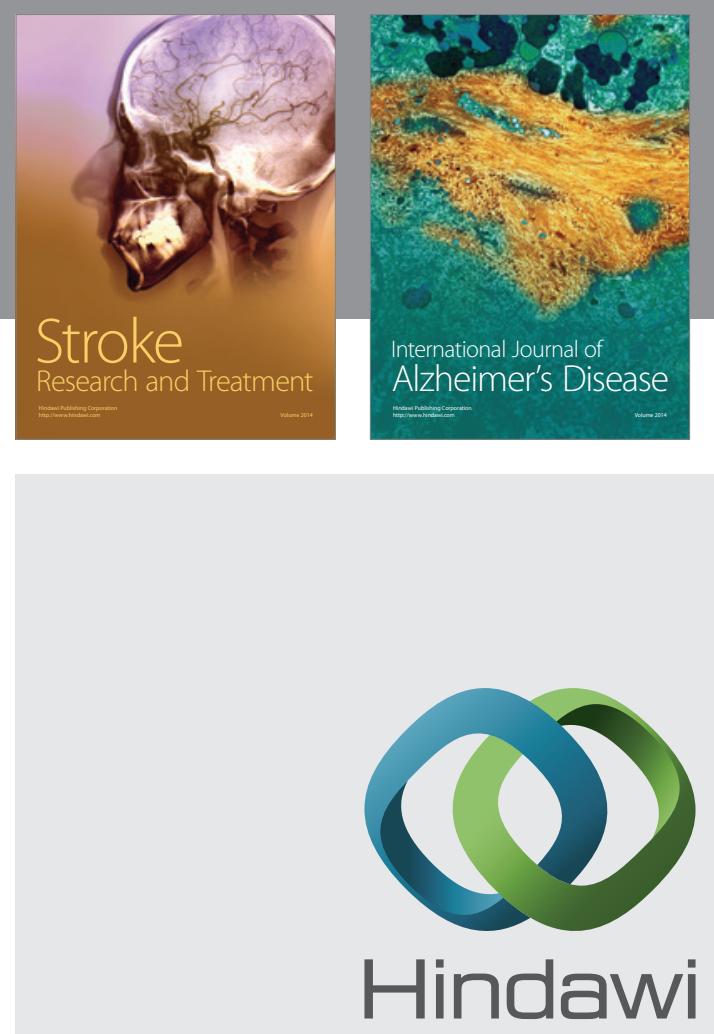

Submit your manuscripts at

http://www.hindawi.com
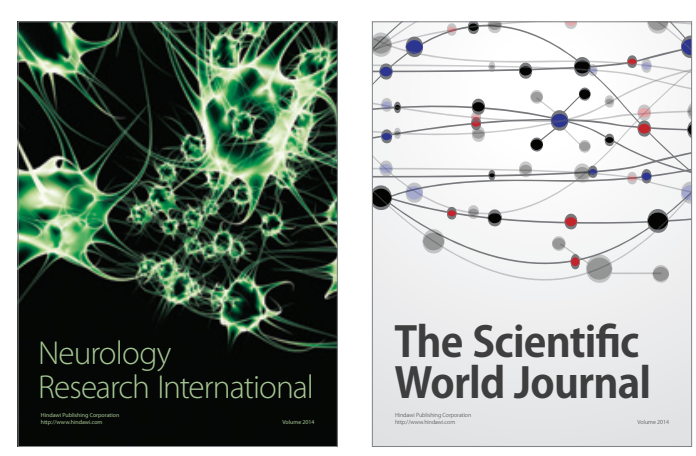

The Scientific World Journal

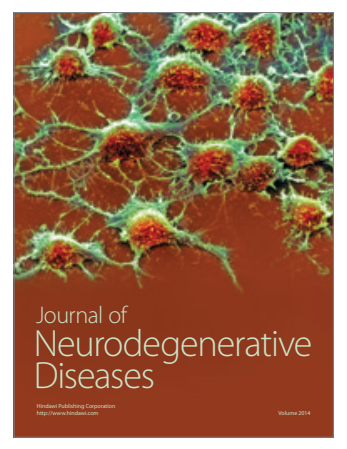

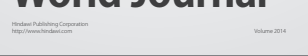

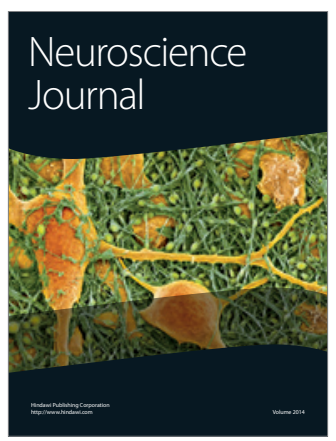

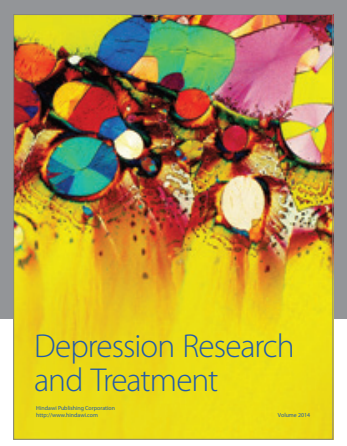
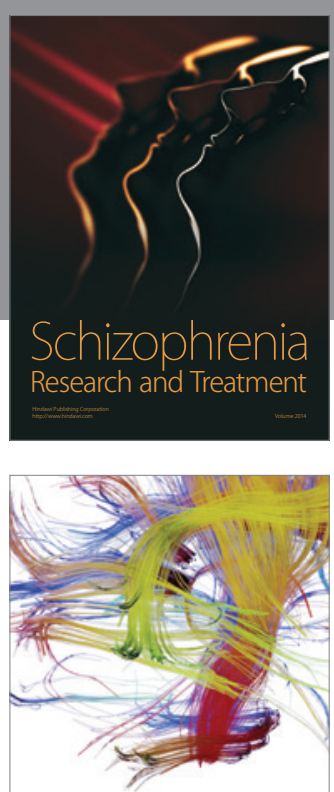

Brain Science

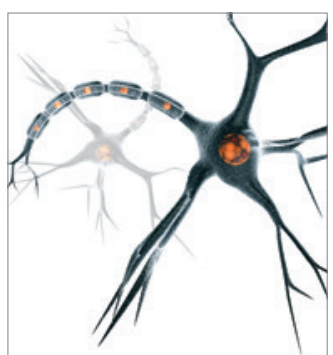

Neural Plasticity
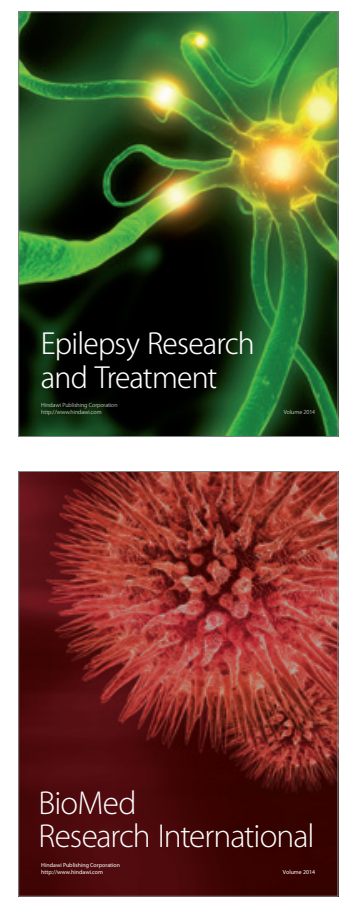

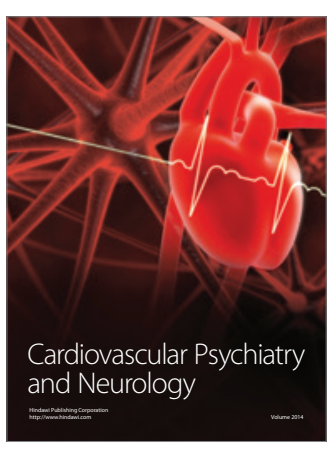

Parkinson's

Disease
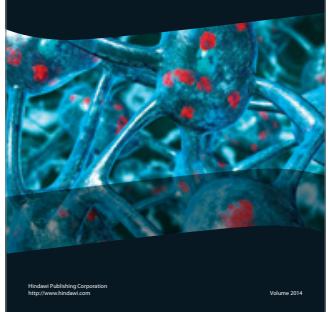